\title{
A study of a system of operator inclusions via a fixed point approach and applications to functional-differential inclusions
}

\section{Adrian Petruşel ${ }^{1}$, GABriela Petruşel ${ }^{2}$ and Jen-ChiH YAO ${ }^{3,4}$}

\section{ABSTRACT.}

In this paper, some existence results for a system of operator inclusions are presented. Qualitative properties of the solution set are also discussed. The method is based on the application of a fixed point theorem for an appropriate operator on the Cartesian product of the given spaces. The approach is new even for the case of the metric spaces. As an application, an existence result for a mixed boundary and initial value problem for a system of second order differential inclusions is given.

Acknowledgement. For the first author, this paper was supported by a grant of the Romanian National Authority for Scientific Research, CNCS-UEFISCDI, project number PNII-ID-PCE-2011-3-0094.

\section{REFERENCES}

[1] Amann, H., Order structures ans fixed points, SAFA 2, University of Calabria, 1977, 1-51

[2] Aubin, J. P., Frankowska H., Set-valued Analysis, Birkhäuser Boston, 1990

[3] Bakhtin, I. A., The contraction mapping principle in almost metric spaces, Funct. Anal.,(1989), No. 30 , Unianowsk, Gos. Ped. Inst., 26-37

[4] Berinde, V., Generalized contractions in quasimetric spaces, Seminar on Fixed Point Theory, 1993, 3-9

[5] Berinde, V., Generalized coupled fixed point theorems for mixed monotone mappings in partially ordered metric spaces, Nonlinear Anal., 74 (2011), 7347-7355

[6] Biles, D. C., Robinson, M. P. and Spraker, J. S., Fixed point approaches to the solution of integral inclusions, Topological Meth. Nonlinear Anal., 25 (2005), 297-311

[7] Coroian, I. and Petruşel, G., Fixed point and coupled fixed point theorems for multi-valued operators satisfying a symmetric contraction condition, Commun. Nonlinear Anal., 1 (2016), 42-62

[8] Covitz, H., Nadler, S. B., Multi-valued contraction mappings in generalized metric spaces, Israel J. Math., 8 (1970), $5-11$

[9] Czerwik, S., Contraction mappings in b-metric spaces, Acta Math. Inform. Univ. Ostraviensis, 1 (1993), 5-11

[10] Czerwik, S., Nonlinear set-valued contraction mappings in b-metric spaces, Atti Sem. Mat. Univ. Modena, 46 (1998), 263-276

[11] Gnana Bhaskar, T. and Lakshmikantham V., Fixed point theorems in partially ordered metric spaces and applications, Nonlinear Anal., 65 (2006), 1379-1393

[12] Guo, D. and Lakshmikantham V., Coupled fixed points of nonlinear operators with applications, Nonlinear Anal., 11 (1987), 623-632

[13] Kirk, W. A. and Shahzad, N., Fixed Point Theory in Distance Spaces, Springer Heidelberg, 2014

Received: 24.05.2016; In revised form: 04.07.2016; Accepted: 10.07.2016

2010 Mathematics Subject Classification. 47H10, 34B15, 54H25.

Key words and phrases. Multi-valued operator, fixed point, ordered metric space, coupled fixed point, data dependence, well-posedness, Ulam-Hyers stability, limit shadowing, measurable selection, integral inclusion, boundary value problem, initial value problem.

Corresponding author: Adrian Petruşel; petrusel@math.ubbcluj.ro 
[14] Mleşniţe, O., Contributions to the study of the coincidence point problem for singlevalued and multivalued operators, Ph.D. Thesis, Babeș-Bolyai University Cluj-Napoca, 2013

[15] Nadler, S. B., Multi-valued contraction mappings, Pacific J. Math., 30 (1969), 475-488

[16] Opoitsev, V. I., Heterogenic and combined-concave operators, Syber. Math. J., 16 (1975), 781-792 (in Russian)

[17] Opoitsev, V. I., A generalization of the theory of monotone and concave operators, Trans. Moscow Math. Soc., 36 (1979), 243-280

[18] Petruşel, A., Petruşel, G., Samet B. and Yao J.-C., Coupled fixed point theorems for symmetric contractions in b-metric spaces with applications to operator equation systems, Fixed Point Theory, 17 (2016), No. 2, 457-476

[19] Petruşel, A., Petruşel, G., Samet, B. and Yao J.-C., Coupled fixed point theorems for symmetric multi-valued contractions in b-metric space with applications to systems of integral inclusions, J. Nonlinear Convex Anal., 17 (2016), No. 7, 1265-1282

${ }^{1}$ BABEŞ-BOLYAi UniVERSity, DEPARTMENT OF MATHEMATICS

400084 CLUJ-NAPOCA, ROMANIA

E-mail address: petrusel@math.ubbcluj.ro

${ }^{2}$ BABEŞ-BOLYAI UNIVERSITY, DEPARTMENT OF BUSINESS

400084 CLUJ-NAPOCA, ROMANIA

E-mail address: gabi.petruseletbs.ubbcluj.ro

${ }^{3}$ China Medical University, Center for General Education

40447 TAICHUNG, TAIWAN

${ }^{4}$ China Medical University Hospital,Research CEnTER For InterneuraComputing

40447 TAICHUNG, TAIWAN

E-mail address: ${ }^{3,4}$ yaojc@mail.cmu.edu.tw 